\title{
Effects of soil nutrient amendments on growth and grain yield perfor- mances of quality protein maize grown under water deficit stress in Ibadan, Nigeria
}

\author{
Folake ANJORIN ${ }^{1,2}$, Adeyinka ADEBAYO ${ }^{1}$, Taiwo OMODELE ${ }^{1}$, and Adewale ADETAYO ${ }^{1}$, James ADED- \\ IRAN
}

Received September 26, 2021; accepted November 15, 2021. Delo je prispelo 26. septembra 2021, sprejeto 15. november 2021

Effects of soil nutrient amendments on growth and grain yield performances of quality protein maize grown under water deficit stress in Ibadan, Nigeria

Abstract: Drought and poor soil fertility are major limitations to crop production, globally. To investigate the impacts of water deficit stress (WS) and soil nutrient amendment (SA) on growth and yield performances of maize. A two years factorial field study was carried out, using a quality protein maize (QPM) (ILE-1-OB) and a non QPM-drought tolerant check (TZPBSR$\mathrm{W})$ varieties in Ibadan. Treatments include; six fertilizer application rates; 50 and $100\left(\mathrm{~kg} \mathrm{~N} \mathrm{ha}^{-1}\right)$ of NPK-20-10-10, $10.7 \mathrm{~kg} \mathrm{~N}$ $\mathrm{ha}^{-1}$ of Tithonia Poultry Compost (TPC), $50 \mathrm{~N}+10.7 \mathrm{TPC}$ and $100 \mathrm{~N}+10.7 \mathrm{TPC}\left(\mathrm{kg} \mathrm{N} \mathrm{ha}^{-1}\right)$, three WS; the control (FW), WS at vegetative stage (STR1), and WS at reproductive stage (STR2). Leaf area (LA) and grain yield (GY) were measured using standard procedures. From the results, across WS, LA ranged from STR1 $(458.90 \pm 12.4)$ to FW $\left(598.81 \pm 13.1 \mathrm{~cm}^{2}\right)$, GY varied from STR2 $\left(2.94 \pm 0.2 \mathrm{t} \mathrm{ha}^{-1}\right)$ to FW $\left(6.59 \pm 0.2 \mathrm{t} \mathrm{ha}^{-1}\right)$, across fertilizers, LA varied from $0 \mathrm{~N}\left(397.65 \mathrm{~cm}^{2}\right)$ to $100 \mathrm{~N}+10.7$ TPC $\left(622.71 \mathrm{~cm}^{2}\right)$ and $50 \mathrm{~N}+10.7$ TPC $\left(611.03 \mathrm{~cm}^{2}\right)$, respectively. The GY varied from $0 \mathrm{~N}\left(2.37 \mathrm{t} \mathrm{ha}^{-1}\right)$ to $100 \mathrm{~N}+10.7 \mathrm{TPC}(5.82$ $\left.\mathrm{t} \mathrm{ha}^{-1}\right)$ and $50 \mathrm{~N}+10.7 \mathrm{TPC}\left(5.26 \mathrm{t} \mathrm{ha}^{-1}\right)$. Drought stress reduced growth and GY performances of QPM, while SA with $50 \mathrm{~kg} \mathrm{~N}$ $\mathrm{ha}^{-1}$ of inorganic fertilizer and $10.7 \mathrm{~kg} \mathrm{~N} \mathrm{ha}^{-1}$ of TPC enhanced growth and grain yield of maize under WS.

Key words: fertilizer application rates; grain yield; growth and yield performances;quality protein maize; soil nutrient amendments; water deficit stress
Učinki gnojenja na rast in pridelek zrnja na proteinih obogatene koruze v razmerah sušnega stresa, Ibadan, Nigeria

Izvleček: Suša in slaba rodovitnost tal sta v globalnem obsegu glavna dejavnika, ki omejujeta produktivnost gojenih rastlin. Za preučevanje vpliva vodnega deficita (WS) in dodajanja hranil v tla (SA) na rast in pridelek koruze je bil izveden dvoletni faktorski poljski poskus na sorti ILE-1-OB, bogati na proteinih (QPM) in na sušo odporni sorti TZPBSR-W kot kontroli, ki ni obogatena s proteini (non QPM), v Ibidanu, Nigerija. Obravnavanja so obsegala: šest načinov gnojenja (50 in 100 (kg $\mathrm{N} \mathrm{ha}^{-1}$ ) z NPK-20-10-10, 10,7 kg N ha-1 komposta iz vrste Tithonia pomešanega s kokošjim gnojem (TPC), $50 \mathrm{~N}+10,7$ TPC in $100 \mathrm{~N}+10,7$ TPC $\left(\mathrm{kg} \mathrm{N} \mathrm{ha}^{-1}\right)$, tri stopnje vodnega deficita (WS) $\mathrm{v}$ vegetativni (STR1) in reproduktivni fazi (STR2) in kontrolo s polnim namakanjem. Listna površina (LA) in pridelek zrnja (GY) sta bila izmerjena s standardnimi metodami. Listna povr-

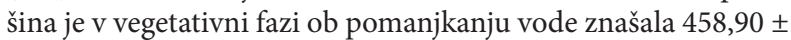
$12,4 \mathrm{~cm}^{2}$, ob polnem zalivanju pa $598,81 \pm 13,1 \mathrm{~cm}^{2}$. Pridelek zrnja je ob vodnem deficitu $\mathrm{v}$ reproduktivni fazi znašal 2,94 \pm $0,2 \mathrm{t} \mathrm{ha}^{-1}$, pri polnem zalivanju pa $6,59 \pm 0,2 \mathrm{t} \mathrm{ha}^{-1}$. Listna površina je bila glede na načine gnojenja sledeča: $0 \mathrm{~N}\left(397,65 \mathrm{~cm}^{2}\right)$, $100 \mathrm{~N}+10,7$ TPC $\left(622,71 \mathrm{~cm}^{2}\right)$ in $50 \mathrm{~N}+10,7$ TPC $(611,03$ $\mathrm{cm}^{2}$ ). Pridelek zrnja je glede na načine gnojenja dosegel naslednje vrednosti: $0 \mathrm{~N}\left(2,37 \mathrm{t} \mathrm{ha}^{-1}\right), 100 \mathrm{~N}+10,7 \mathrm{TPC}\left(5,82 \mathrm{t} \mathrm{ha}^{-1}\right)$ in $50 \mathrm{~N}+10,7 \mathrm{TPC}\left(5,26 \mathrm{t} \mathrm{ha}^{-1}\right)$. Sušni stres je zmanjšal rast in pridelek sorte QPM, gnojenje s $50 \mathrm{~kg} \mathrm{~N}$ ha $^{-1}$ kot anorganskim gnojilom dopolnjeno $\mathrm{z} 10,7 \mathrm{~kg} \mathrm{~N}^{-1} \mathrm{v}$ organski obliki je pospešilo rast in pridelek zrnja koruze v razmerah vodnega deficita.

Ključne besede: na proteinih obogatena koruza; odmerki in vrste gnojil; rast; pridelek zrnja; sušni stress

1 Institute of Agricultural Institute Research and Training, Obafemi Awolowo University, Ibadan, Nigeria

2 Corresponding author, e-mail: folakeawoeyo@yahoo.com 


\section{INTRODUCTION}

Maize is an important cereal crop with wide range of utilization in several countries of the world. Apart from been a major staple crop, maize is an important ingredient in livestock feed formulation for the rising poultry business in the sub Saharan Africa. Maize has remained a unique crop with great potentials to survive across different agro-ecology and vegetations, globally. However, the detrimental impacts of drought and poor soil fertility on profitable maize production in the tropics cannot be overemphasized (Goldblatt, 2010; Ammani et al., 2012). Unpredictable weather conditions, erratic rainfall patterns, and incidences of occasional pockets of drought even at the peak of rains are characteristics attributes of Nigeria's climate, lately. The consequences of climate change are gradually having its turn on the nation's vegetation and cropping system.

An estimated value of about $15 \%$ reductions in global maize production has been attributed to drought alone (Edmeades, 2013). Inadequate water availability affects virtually all physiological and metabolic processes in maize development. Processes such as germination, seedling growth, leaf formation, stem elongation, and overall crop development (Anjorin et al., 2017; Anjorin et al., 2018). The severity of damage resulting from drought stress depends on the duration of drought and the phenological stage of plant development as at time of stress (Chaves et al., 2002; Jongdee et al., 2002). The reproductive developmental stage has been shown to be the most critical stage for maize sensitivity to drought. Monneveeux et al. (2006) in a similar view, reported that grain yield in maize could be drastically reduced by drought prolonged beyond 12 days during grain filling and flowering stages.

Apart from drought, uncontrolled soil nutrient mining due to continuous cropping without supplementary replacement has been a common and regular practice in most countries of sub-Saharan Africa (Ngetich et al., 2012). An estimated average annual nutrient depletion ranged from $20 \mathrm{~kg}$ to $50 \mathrm{~kg} \mathrm{NPK} \mathrm{ha-1} \mathrm{yr}^{-1}$ in majority of developing countries to more than $100 \mathrm{~kg} \mathrm{NPK} \mathrm{ha}^{-1} \mathrm{yr}^{-1}$ in the least developed countries of Africa (Tan et al., 2005).

Crops appear more devastated especially when both drought and nutrient stresses occur simultaneously. However, the use of drought tolerant crop genotypes and fertilizers has the potentials to enhance crop growth and yield in the face of prevailing climatic challenges. Over time, several integrated soil fertility management strategies (ISFM) that could enhance soil fertility potentials and productivity in Africa had been advocated (Scoones \& Toulmin, 1998). These include the use of fertilizers, organic inputs and improved germplasm in addition to the technicalities of adapting these practices to local environments (Vanlauwe et al., 2010; Sanginga \& Woomer, 2009).

Therefore, there is a need for a balance in moisture and nutrient availability in the crop environment with regards to stages of plant development for optimum crop yield. As at present much work has not been carried out in this part of the world on soil fertility management strategies with regards to occurrences of drought during various phenological growth stages in maize. Hence, this study aimed at assessing the impact of inorganic and organic fertilizers (using Tithonia poultry compost) soil amendment interventions at ameliorating the impact of water deficit stress (drought) on maize phenology.

\section{MATERIALS AND METHODS}

\subsection{EXPERIMENTAL SITE, LOCATION AND DE- SIGN}

The study was conducted on the research field (Longitude $3^{\circ} 50^{\prime} 56.1^{\prime \prime} \mathrm{E}$ and latitude $7^{\circ} 22^{\prime} 20^{\prime \prime} \mathrm{N}$ ) during the dry seasons between Decembers - March in 2014/ 2015 and 2015/2016 at the Institute of Agricultural Research and Training (I.A.R\&T), Moor Plantation in Ibadan. The I.A.R\&T is located in the derived savanna agro ecology of Nigeria (Figure 1).

\subsection{TREATMENTS}

\subsubsection{Water Deficit Stress}

(i) No water stress (FW): plots receive water up to field capacity till plant maturity

(ii) Water stress for 14 days (withdrawn of watering) at three weeks after seedling emergence, while normal watering resumed till plant maturity (STR1)

(iii)Water stressed imposed in maize plots by water withdrawer for 14 days at 6 weeks after seedling emergence after which normal watering resumed till plant maturity (STR2).

\subsubsection{Fertilizer rates}

(i) Three rates of $\mathrm{N}$ fertilizer (NPK-20-10-10); $0 \mathrm{~N}$, $50 \mathrm{~N}, 100 \mathrm{~N}\left(\mathrm{~kg} \mathrm{ha}^{-1}\right)$

(ii) One rate of Tithonia - Poultry Compost (TPC): 10 TPC $\left(\mathrm{t} \mathrm{ha}^{-1}\right)\left(10.7 \mathrm{~kg} \mathrm{~N} \mathrm{ha}^{-1}\right)$, 


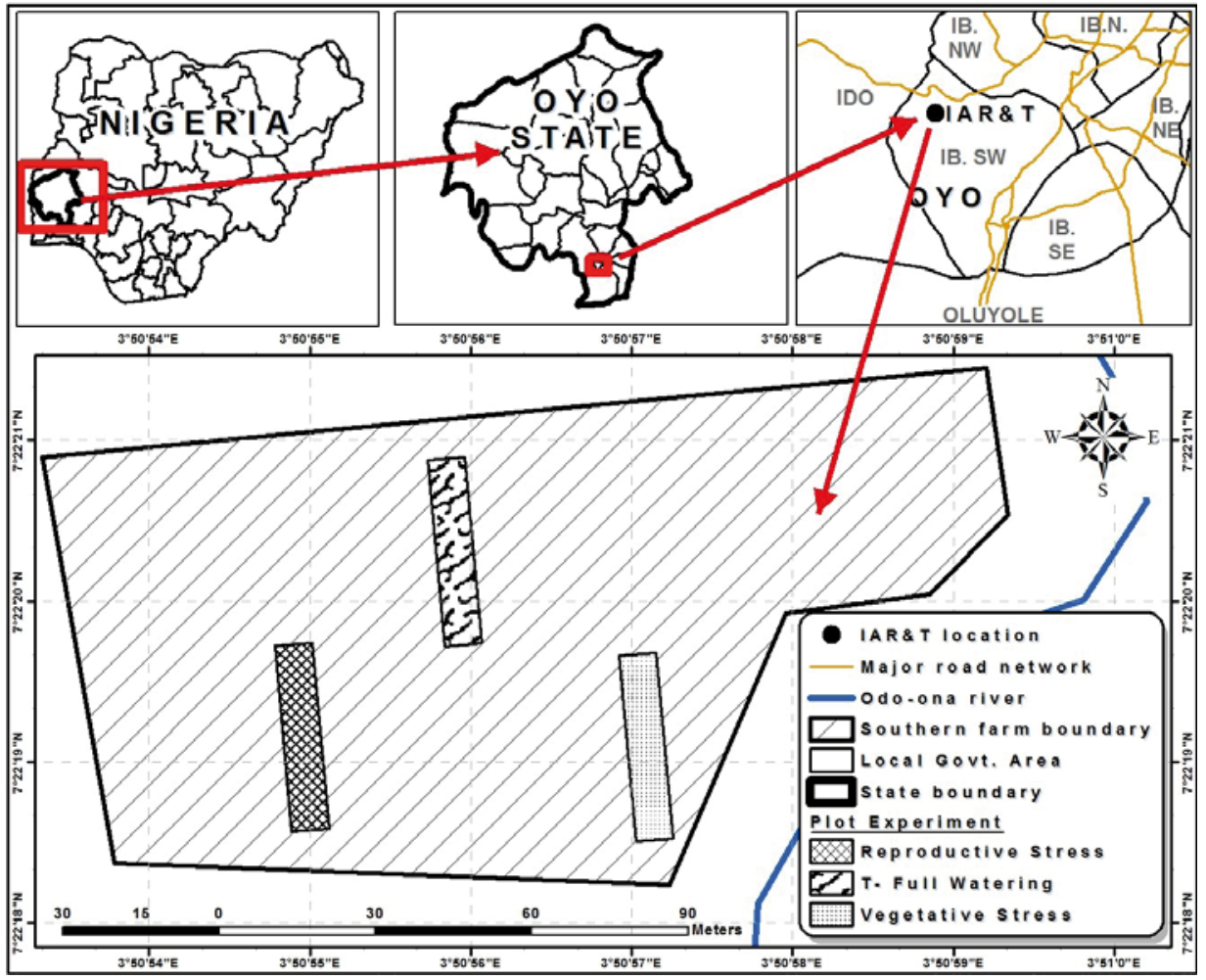

Figure 1: Map showing the experimental plots and location of the experiment at the Institute of Agricultural Research and Training in Ibadan, Oyo state, Nigeria

(iii) Two rates of $\mathrm{N}$ fertilizer and TPC combinations; $50 \mathrm{~N}+10 \mathrm{TPC}$ and $100 \mathrm{~N}+10 \mathrm{TPC}$.

\subsubsection{Varieties}

Two maize varieties consisting of one quality protein maize variety (ILE-1-OB) and a drought tolerant maize (TZPBSR-W) (Smale et al., 2011) are both open pollinated (intermediate maturing) high yielding characterized by flint texture and white colour seeds, were collected from the seed store of I.A.R \& T, Ibadan.

\subsubsection{Experimental design}

The maize field was planted in $3 \times 6 \times 2$ factorial arrangements using randomized complete block design ( $\mathrm{r}$ $=3$ ). Each of the three main plots was $27.5 \mathrm{~m}$ by $14 \mathrm{~m}$ in size were separated by $5 \mathrm{~m}$ apart to prevent water seepage across the main plot during irrigation processes, the sub-plot was $4 \mathrm{~m} \times 7.5 \mathrm{~m}$ while the sub-sub plot was $4 \mathrm{~m}$ x $3.75 \mathrm{~m}$. There were thirty - six plots in the each main plot, each of the sub - sub plot consisted of six (6) rows of two plants per hill at a planting distance of $75 \mathrm{~cm} \mathrm{x} 50 \mathrm{~cm}$ inter rows and intra rows spacing, respectively.

\subsection{LAND PREPARATION, PLANTING AND CROP MANAGEMENT}

The pre crop for both first and second year is maize. The land was prepared mechanically by ploughing and harrowing. Initial wetting was done before each of the operations to ease the operations because the land was very dry and compacted as expected during the dry season. After land preparations, maize seeds were sown at three seeds per hill. The young maize seedlings down to two vigorous healthy seedlings per stand. Pre emergence herbicides (Atrazin $4 \mathrm{~kg} \mathrm{ha}^{-1}$ and Glyphosate) were applied to control weeds, while subsequent weeding was done with local hoes.

\subsection{COMPOST PREPARATION AND FERTILIZER APPLICATION}

The compost was prepared from fresh cuttings of Mexican sunflower (Tithonia diversifolia (Hemsl.) us- 
ing the heap method described by Fernhill, (2011). Nine (9) kilogram of Mexican sun flower (Tithonia diversifolia) plant cuttings of about 10 centimeters long were weighed, chopped and spread on the earth surface. The spread plant cuttings were alternated in layers with the spreading of three kilogram $(3 \mathrm{~kg}$ ) of cured fecal poultry droppings to form heap of $1.3 \mathrm{~m}$ height. Several heaps made were sprinkled with water before covering with black polythene sheet to increase temperature, moisture maintenance and escape of gases. The heaps were over turned fortnightly with the aid of long garden fork and moisturized adequately to enhance effective microbial growth and activities. Adequate aeration was achieved using $1 \mathrm{~m}$ diameter pipes inserted vertically and horizontally into the heaps to ensure adequate ventilation. The $\mathrm{pH}$ and temperature were monitored until the compost matured (AAFRD, 2005). The compost heaps were allowed to stay for a period of $2^{1}$ months after which the compost materials were ready for use. The compost material was spread thinly on a drying surface under shade and allowed to dry very well before storing in bags. Sample of the matured compost were analysed for chemical properties (Anjorin, 2018). Compost was applied a-week before planting to each of the designated plots to initiate early mineralization of nutrients. Inorganic fertilizer (urea) was applied to the designated plots in splits at two weeks and five weeks after emergence based on the pre determined rate.

\subsection{IRRIGATION}

Irrigation was done using sprinklers while tensiometer (Eijkelkamp.co) was used to monitor the soil water potential.

\subsection{DATA COLLECTION}

- Plant height (using meter rule and measured in centimeter from the base of the plant to the base of the last emerged leaf).

- Leaf area (obtained by measuring in $\mathrm{cm}^{2}$ using the meter rule to measure the length of a fully expanded tagged leaf and the breadth at mid leaf. The product of the length and the width was multiplied by 0.75 which is the calibration factor for maize leaf (Francis et al., 1969).

- Number of ears per plant (by visual counting)

- Number of rows per cob, number of kernels per row (by visual counting), number of kernels per cob (obtained by multiplying the number of kernels per rows with number of rows per cob), cob length (measuring the length of a cob using the meter rule)

- Grain yield was taken from total ear harvest per plot.

- Mass of 1000 grains and total grain yield (after

\section{RF (mm) 公RF (days) K Min Temp N゙Max. Temp 圈 R.H}

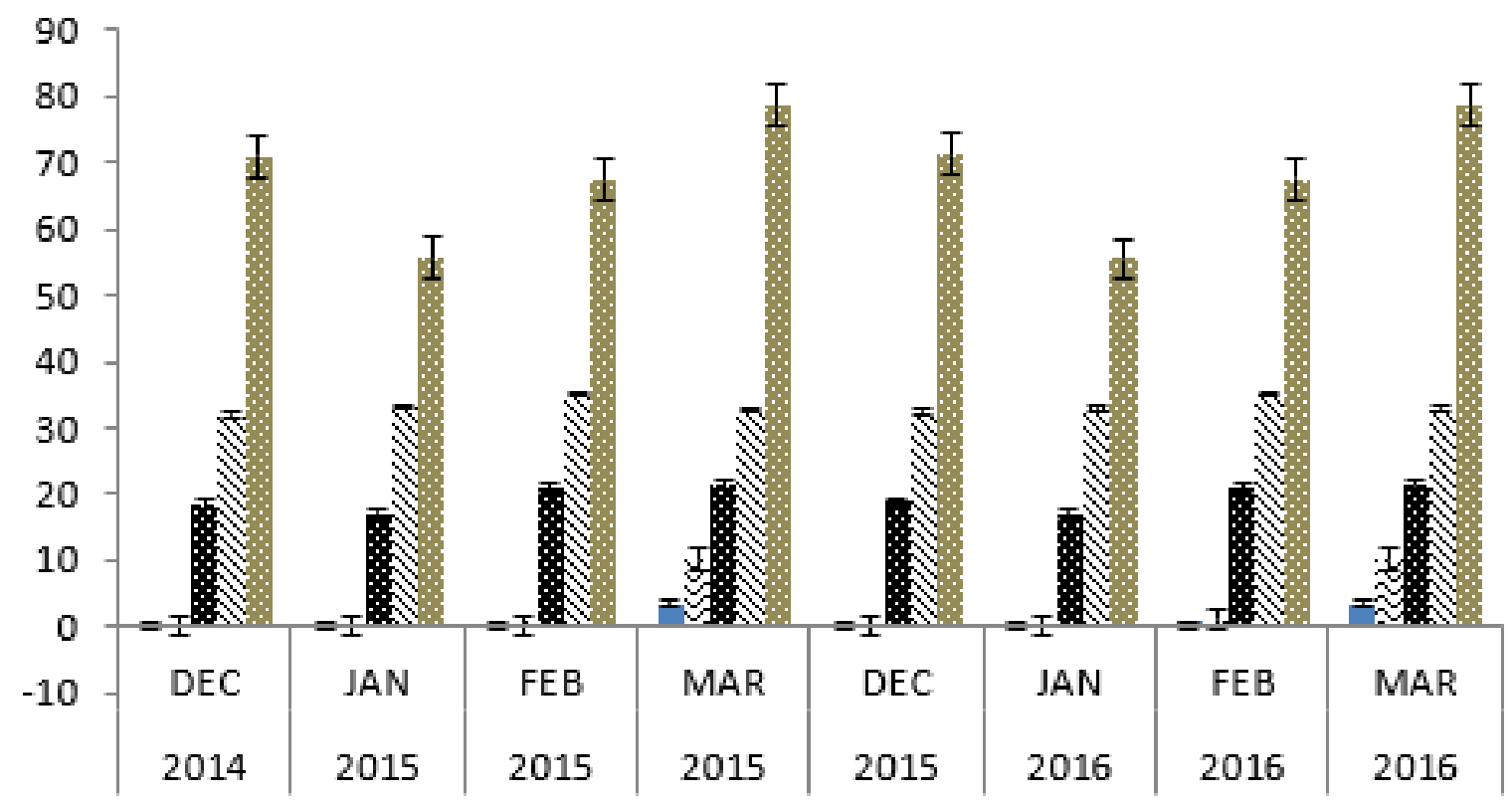

Figure 2: Mean monthly temperature $\left({ }^{\circ} \mathrm{C}\right)$, humidity and precipitation (mm) during 2014, 2015 and 2016 planting seasons. Source: Nigerian Meteorological Agency, Ibadan (NIMET) 
adjusting to $12 \%$ moisture content) using weighing balance.

\subsection{DATA ANALYSIS}

The data collected were pooled across the two years and subjected to analysis of variance (ANOVA) for split - split - split plot in RCBD using Statistical Tool For Agricultural Research (STAR, version 2.0.1 2014). Significant means were separated using Tukey Honest Significant Difference at $5 \%$ probability level.

\section{RESULTS}

\subsection{WEATHER INFORMATION}

The mean monthly temperature $\left({ }^{\circ} \mathrm{C}\right)$, humidity and precipitation $(\mathrm{mm})$ during the experimental studies were shown in Figure 2. No rainfall was recorded for the months of December, January, February (actual periods when water deficit stress was imposed). About 3.43 and $3.49 \mathrm{~mm}$ total number of rainfall were recorded in March in 2015 and 2016, respectively. Maximum temperatures were recorded in February while relative humidity values were significantly reduced in January and February of the years of the trials.

\subsection{SOIL PHYSICO-CHEMICAL PROPERTIES}

The soil obtained from the experimental field was a loamy-sandy soil of classification series "Typic Kanhaplustalf". Result of the chemical analyses showed that there were slight variations in the soil chemical properties in the two years of the experimental studies (Table 1). The $\mathrm{pH}$ value of the soil samples appeared slightly acidic in 2015 (6.00) and slightly basic in 2016 (7.25). Soil total nitrogen (0.06\%, $0.05 \%)$, available phosphorus (13.16 $\left.\mathrm{mg} \mathrm{kg}{ }^{-1}, 6.84 \mathrm{mg} \mathrm{kg}^{-1}\right)$, organic carbon (0.44 \%, $\left.0.86 \%\right)$, potassium and the micronutrients were very low in 2015 and 2016 compared with recommended soil requirement for Nigerian soils.

\subsection{CHEMICAL PROPERTIES OF COMPOST USED}

The compost was slightly basic with $\mathrm{pH}$ value of 8.30 , total nitrogen content was $0.70 \%$, while the values of phosphorus and potassium were $0.91 \mathrm{mg} \mathrm{kg}^{-1}$ and $0.61 \mathrm{cmol} \mathrm{kg}^{-1}$, respectively (Table 2). The compost had high carbon to nitrogen ratio value (7.47), and very high micronutrients (Iron (9587), Zinc (436) and manganese (597) $\mathrm{mg} \mathrm{kg}^{-1}$ ).

\subsection{PLANT HEIGHT (PHT)}

Water deficit stress significantly influenced plant height and fertilizer application rates $(p<0.001)$ (Table 3 ). Significant reduction in plant heights were observed in maize subjected to water deficit stress at three weeks after emergence compared with maize grown under FW and STR2, plant heights ranged from $119.79 \mathrm{~cm}$ (STR1) to $150.76 \mathrm{~cm}$ (FW) (Table 4). Across the fertilizer rates, maize heights ranged between $116.88 \mathrm{~cm}(0 \mathrm{~N})$ to 141.18 $\mathrm{cm}(100 \mathrm{~N}+10 \mathrm{TPC})$, there was no significant difference in the plant heights observed across the fertilizer application rates, except for the control which had relatively shorter plants. Maize variety TZPBSR-W $(136.43 \mathrm{~cm})$ are taller than ILE-1-OB $(132.01 \mathrm{~cm})$.

Table 1: Pre-planting physico - chemical properties of soil used for the experiments

\begin{tabular}{|c|c|c|}
\hline & 2015 & 2016 \\
\hline \multicolumn{3}{|l|}{ Parameter } \\
\hline $\mathrm{pH}\left(\mathrm{H}_{2} 0\right)$ & 6.00 & 7.25 \\
\hline Organic carbon (\%) & 0.44 & 0.86 \\
\hline Total nitrogen (\%) & 0.06 & 0.05 \\
\hline Available P (mg kg$\left.{ }^{-1}\right)$ & 13.16 & 11.84 \\
\hline Bulk density $\left(\mathrm{Mg} \mathrm{m}^{-3}\right)$ & 1.31 & 1.31 \\
\hline $\mathrm{ECEC}(\mathrm{cmol})$ & 7.11 & 5.56 \\
\hline Base saturation (\%) & 99.02 & 99.28 \\
\hline \multicolumn{3}{|c|}{ Exchangeable cation $\left(\mathrm{cmol} \mathrm{kg}^{-1}\right)$} \\
\hline $\mathrm{K}$ & 0.22 & 0.37 \\
\hline $\mathrm{Na}$ & 0.39 & 0.63 \\
\hline $\mathrm{Ca}$ & 5.53 & 3.80 \\
\hline $\mathrm{Al}+\mathrm{H}$ & 0.07 & 0.04 \\
\hline \multicolumn{3}{|c|}{$\begin{array}{l}\text { Exchangeable micronutrient } \\
\left(\mathrm{mg} \mathrm{kg}^{-1}\right)\end{array}$} \\
\hline $\mathrm{Fe}$ & 7.10 & 0.06 \\
\hline $\mathrm{Zn}$ & 3.60 & 0.65 \\
\hline $\mathrm{Cu}$ & 1.10 & 0.15 \\
\hline $\mathrm{Mn}$ & 22.8 & 44.10 \\
\hline \multicolumn{3}{|l|}{ Soil particle analysis } \\
\hline Sand $\mathrm{g} \mathrm{kg}^{-1}$ & 854 & 842 \\
\hline Silt $\mathrm{g} \mathrm{kg}^{-1}$ & 82 & 86 \\
\hline Clay $\mathrm{g} \mathrm{kg}^{-1}$ & 64 & 72 \\
\hline Textural class & $\begin{array}{l}\text { loamy } \\
\text {-Sandy }\end{array}$ & $\begin{array}{l}\text { loamy } \\
\text {-Sandy }\end{array}$ \\
\hline
\end{tabular}


Table 2: Chemical properties of the Tithonia poultry compost used as soil amendment

\begin{tabular}{ll}
\hline Parameter & Values \\
\hline $\mathrm{pH}\left(\mathrm{H}_{2} 0\right)$ & 8.30 \\
Organic carbon (\%) & 5.25 \\
Total nitrogen (\%) & 0.70 \\
Available P $\left(\mathrm{mg} \mathrm{kg}^{-1}\right)$ & 0.91 \\
$\mathrm{C} / \mathrm{N}$ ratio & 7.47 \\
Exchangeable cation $\left(\mathrm{cmol} \mathrm{kg}^{-1}\right)$ & \\
$\mathrm{K}$ & 0.61 \\
$\mathrm{Na}$ & 0.62 \\
$\mathrm{Ca}$ & 4.95 \\
$\mathrm{Mg}$ & 0.92 \\
$\mathrm{Exchangeable} \mathrm{micronutrient}\left(\mathrm{mg} \mathrm{kg}^{-1}\right)$ & \\
$\mathrm{Fe}$ & 9587 \\
$\mathrm{Zn}$ & 436 \\
$\mathrm{Cu}$ & 31.0 \\
$\mathrm{Mn}$ & 597 \\
\hline
\end{tabular}

Water deficit stress and fertilizer interaction (WS x F) effect on plant height was significant $(p<0.05)$. Plant height ranged from $0 \mathrm{~N}(99.99 \mathrm{~cm})(\mathrm{STR} 1)$ to $160.40 \mathrm{~cm}$ 10 TPC (FW) (Figure 3a). Plant heights at STR1 across the various fertilizers application rates were not significantly different but higher than $0 \mathrm{~N}(99.99 \mathrm{~cm})(p<0.05)$. Highest plant height was observed at $10 \mathrm{TPC}(160.40 \mathrm{~cm})$ (FW) but lowest at $0 \mathrm{~N}$ (STR1).

Water deficit stress and variety interaction (WS $\mathrm{x} V$ ) interaction effect on plant heights was significant $(p<0.05)$ (Table 5). Maize variety TZPBSR-W (160.26 $\mathrm{cm})$ had taller stems under full watering than ILE-1-OB $(149.18 \mathrm{~cm})$, however no differences observed in the heights at STR1 and STR2, respectively.

\subsection{LEAF AREA (LA)}

Leaf area differed significantly across water deficit stress and fertilizer application rates $(p<0.001)$ (Table 3$)$. The leaf areas varied from $458.90 \mathrm{~cm}^{2}$ (STR1) to $598.81 \mathrm{~cm}^{2}$ (FW) (Table 4). Across F rates, the largest leaf area size was observed when $100 \mathrm{~N}+10 \mathrm{TPC}$ was applied $\left(622.71 \mathrm{~cm}^{2}\right)$, this LA value was however not significantly different from LA's obtained when $50 \mathrm{~N}+10$ TPC $\left(611.03 \mathrm{~cm}^{2}\right)$ and 10 TPC $\left(581.57 \mathrm{~cm}^{2}\right)$ were applied, while the control $(0 \mathrm{~N})$ had least LA size of $397.65 \mathrm{~cm}^{2}$. The leaf areas of the two maize varieties were not significantly different.

Water deficit stress and fertilizer interaction (WS $\mathrm{x}$
F) effect on LA was significant $(p<0.001)$ (Figure $3 b$ ). Large leaf area (LA) sizes of maize plant were observed at $100 \mathrm{~N}+10 \mathrm{TPC}\left(645.31 \mathrm{~cm}^{2}\right)$ and $50 \mathrm{~N}+10 \mathrm{TPC}$ $\left(647.47 \mathrm{~cm}^{2}\right)$ under FW. The leaf areas obtained were not significantly different from LA's obtained under $50 \mathrm{~N}$ and $100 \mathrm{~N}$ and 10 TPC fertilizer applications rates except $0 \mathrm{~N}$ $\left(465.11 \mathrm{~cm}^{2}\right)$. Similar trend was observed in STR2 across the fertilizers application rates. Significant reduction in leaf sizes were observed in STR1 across the fertilizer rates, however considerably larger leaf area sizes were observed with applications of $100 \mathrm{~N}+10 \mathrm{TPC}\left(541.47 \mathrm{~cm}^{2}\right)$ and $50 \mathrm{~N}+10 \mathrm{TPC}\left(528.19 \mathrm{~cm}^{2}\right)$, respectively.

\subsection{NUMBER OF EAR PER PLANT (E/P)}

The number of ear per plant was not significantly influenced by WS $(p<0.05)$ (Table 3$)$, however the E/P varied significantly across fertilizer application rates $(p<$ $0.01)$. Applications of $100 \mathrm{~N}+10 \mathrm{TPC}(1.57)$ and $50 \mathrm{~N}+$ 10 TPC (1.60) produced more ear per plant than other F-application rates and the control which had the least value of 1.27 of ear per plant.

Fertilizer and variety interaction $(\mathrm{F} x \mathrm{~V})$ effects on number of ear per plant of two maize was significant $(p<$ $0.05)$. Maize variety ILE-1-OB (1.39) had fewer numbers of ears than TZPBSR-W (1.15) under the control, maize variety TZPBSR-W (1.55) had more ears than ILE-1-OB (1.35) under $100 \mathrm{~N}$ (Table 6).

\subsection{COB LENGTH (CBT)}

The cob length was significantly influenced by water deficit stress and fertilizer application rates $(p<0.001)$ (Table 3), across WS, the cob length ranged from 12.46 $\mathrm{cm}$ (STR2) to $18.02 \mathrm{~cm}$ (FW) (Table 4). Cobs length ranged between $0 \mathrm{~N}(12.02 \mathrm{~cm})$ to $100 \mathrm{~N}+10 \mathrm{TPC}(16.44$ $\mathrm{cm})$. However, no significant difference was observed between cob lengths of $100 \mathrm{~N}(15.45 \mathrm{~cm})$ and $10 \mathrm{TPC}$ $(15.28 \mathrm{~cm})$.

\subsection{NUMBERS OF ROWS PER COB (R/C)}

Water deficit stress and fertilizer significantly influenced number of rows per cob $(p<0.001)$ (Table 3 ). The effect of WS on R/C, varied between STR2 (11.83) to FW (13.72), while applications of $100 \mathrm{~N}+10 \mathrm{TPC}$ and $50 \mathrm{~N}+10 \mathrm{TPC}$ and $100 \mathrm{~N}$ had the highest number of rows per cob compared with $\mathrm{R} / \mathrm{C}$ of other fertilizer applications rates but lowest in the control (11.03) (Table 


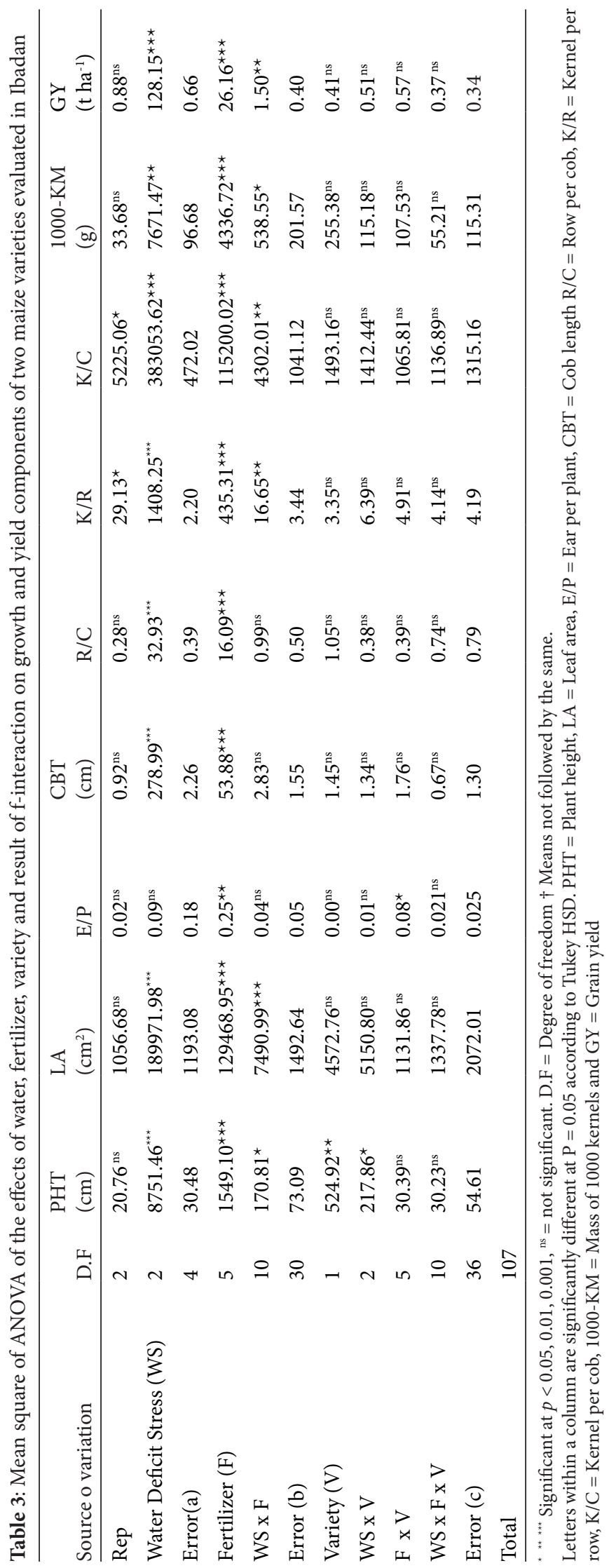




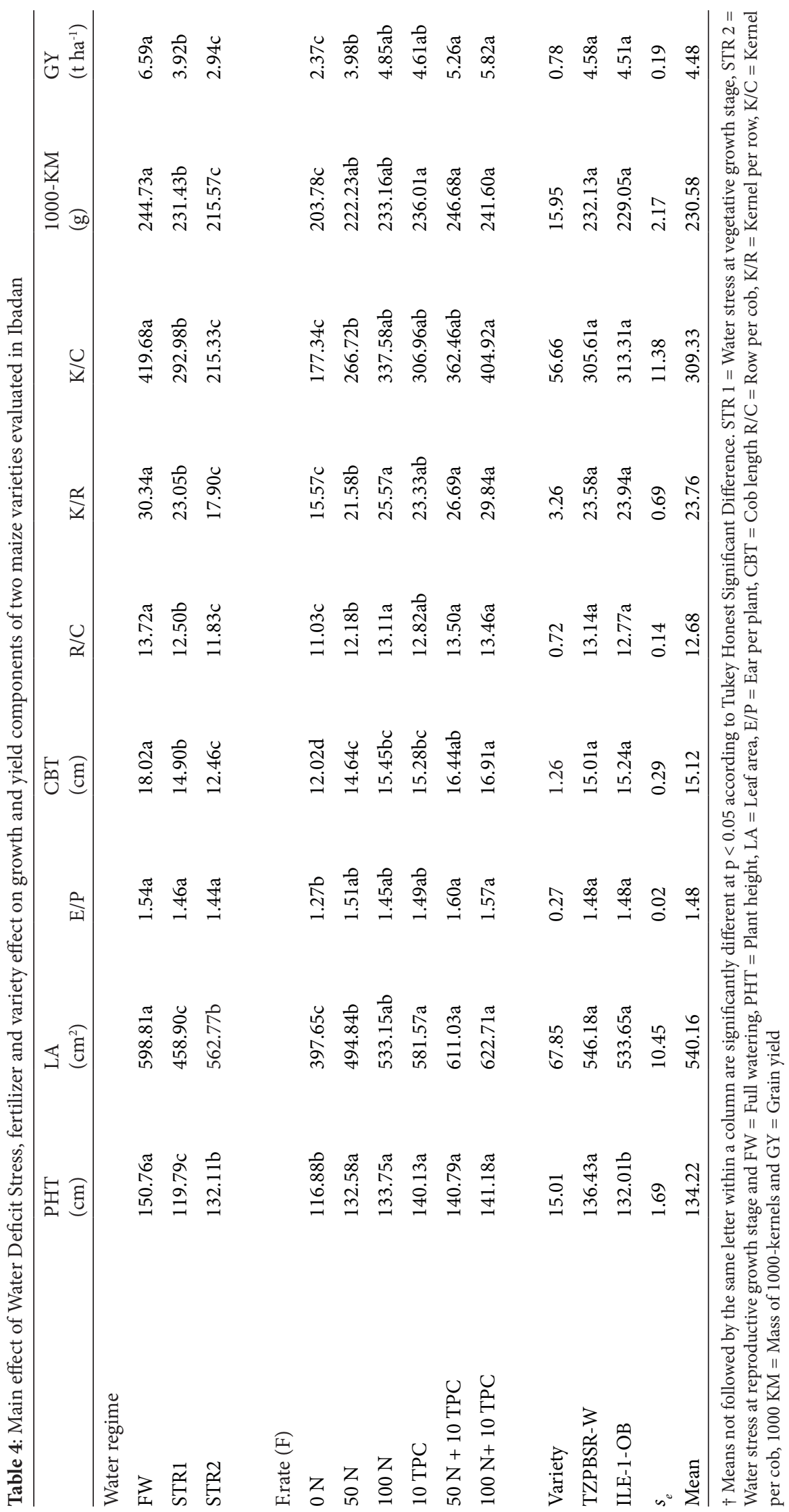


4). Interaction effects on number of rows per cob were not significant

\subsection{NUMBERS OF KERNELS PER ROW (K/R)}

Number of kernels per row varied across the replicates $(p<0.05)$, WS and $\mathrm{F}(p<0.001)$ and WS $\times \mathrm{F}(0.01)$ (Table 3). Effect of WS on K/R was the lowest at STR2 (17.90) but the highest at FW (30.34), across fertilizer application rates (Table 4). Across SA rates, the number of kernel per row also ranged between $0 \mathrm{~N}(15.57)$ to $100 \mathrm{~N}$ +10 TPC (29.84), though number of K/R at $100 \mathrm{~N}+10$ TPC was not significantly different from $\mathrm{K} / \mathrm{R}$ recorded for $50 \mathrm{~N}+10$ TPC (26.69) and $100 \mathrm{~N}$ (25.57). The number of kernels per row ranged from $0 \mathrm{~N}$ (22.64) to 100 $\mathrm{N}+10$ TPC (34.37) under FW, while no significant difference among K/R formed by the applications of $100 \mathrm{~N}$ +10 TPC (34.37), $50 \mathrm{~N}+10 \mathrm{TPC}$ (28.79) and $10 \mathrm{TPC}$ (32.99) (Figure 3c). High significant reductions in number K/R was observed at STR2 and K/R ranged from $0 \mathrm{~N}$ (9.76) to $100 \mathrm{~N}+10$ TPC (24.37) followed by $50 \mathrm{~N}+10$ TPC (21.59).

\subsection{NUMBERS OF KERNELS PER COB (K/C)}

The numbers of kernels per cob varied significantly across the replicates $(p<0.05)$, WS and $\mathrm{F}(p<0.001)$ and WS x F ( $p<0.01)$ (Table 3$)$. Effect of WS on K/C varied from STR2 (215.33) to FW (419.68) (Table 4). Across Frates, the highest number of kernel per cob was recorded at $100 \mathrm{~N}+10 \mathrm{TPC}(404.92)$ and the lowest in the control (177.34), number of kernels per cob at $100 \mathrm{~N}, 10 \mathrm{TPC}$ and $50 \mathrm{~N}+10 \mathrm{TPC}$ were not significantly different. Water deficit stress and fertilizer interaction effect was significant on $\mathrm{K} / \mathrm{C}$, least number of $\mathrm{K} / \mathrm{C}$ was obtained at STR2 (98.86) while application of $100 \mathrm{~N}+10 \mathrm{TPC}$ (514.94) gave highest number of $\mathrm{K} / \mathrm{C}$ at FW.

\subsection{MASS OF1000-KERNELS (1000-KM)}

The mass of 1000-kernels was significantly influenced by WS $(p<0.01), \mathrm{F}(p<0.001)$ and WS $\times$ F $(p$ $<0.05$ ) (Table 3). The effect of WS on 1000-kernel mass varied from STR2 $(215.57 \mathrm{~g})$ to FW $(244.73 \mathrm{~g})$ (Table 4). Across the fertilizer application rates, the mass of 1000 -kernel was the highest at $50 \mathrm{~N}+10$ TPC $(246.68 \mathrm{~g})$, though not significantly different from 1000-KM of 100 $\mathrm{N}+10 \mathrm{TPC}(241.60 \mathrm{~g})$ and $10 \mathrm{TPC}(236.01 \mathrm{~g})$, while the control had the least value of $203.78 \mathrm{~g}$.

Water deficit stress, fertilizer interaction effect shows that the highest 1000-kernel mass was obtained at $50 \mathrm{~N}+10$ TPC under FW (266.13 g), this value was not significantly different from 1000-kernel mass observed at $100 \mathrm{~N}+10 \mathrm{TPC}(261.38 \mathrm{~g}), 10 \mathrm{TPC}(257.78 \mathrm{~g})$ and 10 TPC (257.50 g), while the smallest value of 1000 -kernel mass was observed under STR2 at $0 \mathrm{~N}(179.10 \mathrm{~g})$. Across STR1, the mass of 1000-kernels were not significantly different.

\subsection{GRAIN YIELD (GY)}

Grain yield varied significantly at WS, F $(p<0.001)$ and WS $\times$ F $(p<0.01)$ (Table 3$)$. The effect of WS on GY ranged between STR2 $\left(2.94 \mathrm{t} \mathrm{ha}^{-1}\right)$ and FW $\left(6.59 \mathrm{t} \mathrm{ha}^{-1}\right)$ (Table 4). Across F- applications, $100 \mathrm{~N}+10 \mathrm{TPC}(5.82 \mathrm{t}$ $\left.\mathrm{ha}^{-1}\right)$ and $50 \mathrm{~N}+10$ TPC $\left(5.26 \mathrm{tha}^{-1}\right)$ produced the highest GY, while the control showed the least GY ( $2.37 \mathrm{t}$ ha $\left.{ }^{1}\right)$. Application of $8.33 \mathrm{tha}^{-1}(100 \mathrm{~N}+10 \mathrm{TPC})$ under FW

Table 5: Water deficit stress and Variety interaction effect on plant heights of two maize varieties in Ibadan

\begin{tabular}{lll}
\hline Water stress & Variety & Plant height \\
\hline FW & ILE-1-OB & $149.18 \pm 5.18$ \\
& TZPBSR-W & $160.26 \pm 4.06$ \\
STR1 & ILE-1-OB & $126.03 \pm 3.27$ \\
& TZPBSR-W & $128.90 \pm 2.54$ \\
STR2 & ILE-1-OB & $141.80 \pm 4.96$ \\
& TZPBSR-W & $139.76 \pm 4.42$ \\
\hline
\end{tabular}

STR $1=$ Water stress at vegetative growth stage, STR $2=$ Water stress at reproductive growth stage and $\mathrm{FW}=$ Full watering

Table 6: Variety and fertilizer application rates interaction effects on number of ear per plant of two maize varieties in Ibadan

\begin{tabular}{lll}
\hline Fertilizer & Variety & Number of earper plant \\
\hline $0 \mathrm{~N}$ & ILE-1-OB & $1.39 \pm 0.08$ \\
& TZPBSR-W & $1.15 \pm 0.06$ \\
$50 \mathrm{~N}$ & ILE-1-OB & $1.52 \pm 0.06$ \\
& TZPBSR-W & $1.49 \pm 0.11$ \\
$100 \mathrm{~N}$ & ILE-1-OB & $1.35 \pm 0.05$ \\
& TZPBSR-W & $1.55 \pm 0.06$ \\
$10 \mathrm{TPC}$ & ILE-1-OB & $1.43 \pm 0.07$ \\
& TZPBSR-W & $1.54 \pm 0.08$ \\
$50 \mathrm{~N}+10 \mathrm{TPC}$ & ILE-1-OB & $1.64 \pm 0.11$ \\
& TZPBSR-W & $1.55 \pm 0.07$ \\
$100 \mathrm{~N}+10 \mathrm{TPC}$ & ILE-1-OB & $1.58 \pm 0.06$ \\
& TZPBSR-W & $1.57 \pm 0.07$ \\
\hline
\end{tabular}


produced the highest GY, while GY was the lowest at $0 \mathrm{~N}$ under STR2 $\left(0.88 \mathrm{t} \mathrm{ha}^{-1}\right)$ (Figure 3f). The GY of the two maize varieties were not significantly different $(p<0.05)$.

\section{DISCUSSION}

Drought and low soil fertility are major abiotic factors militating against profitable maize production in the tropics. The use of drought tolerant crop genotypes and soil amendment has potential to enhance growth and yield performances of crops grown under drought condition. To investigate the role of soil nutrient amendment on the growth and yield responses of crop to water deficit stress, field experiment was established in Ibadan, Nigeria.

Results obtained show that 14 days withdrawal of watering during the vegetative growth stage (STR1) resulted in maize plants with reduced heights and leaf areas. The reduction in leaf area as a result of water deficit stress may be attributed to decrease in rate of leaf initiation and expansion and or accelerated rate of leaf senescence and leaf shedding which consequently reduce grain yield compared with grain yield obtained under well watered condition (Bolaños \& Edmeades, 1996; Nam et al., 1998; Anjum et al., 2011). As leaves with reduced leaf area do not fully intercept solar radiation which in turn strikes the ground, and consequently increased the evaporation - transpiration ratio (Araus, 2002). Reduction in plant height from water deficit stress interferes with over all crop photosynthetic efficiency (Imadi et al., 2016). Hence, plants with greater heights are often larger in overall plant size, intercept more light and use water faster by transpiration.

In this study, water deficit stress at vegetative stage (STR1) accounted for $41 \%$ loss in grain yield, this finding agreed with the report of Rufino et al. (2018). Water deficit stress affects all the various metabolic processes and yield components in plant and in turn reduced crop yield potential. Borra's et al. (2003), inferred that the overall indirect impact of water stress during vegetative stage on grain yield is source limiting as water stress decreased the source potential and available assimilates level and decreases grain weight. For instance, the kernel rows in maize are determined between V7 to V8 maize growth phase, while the number of kernels on each ear and size of ear in maize is determined at V12 of the maize growth stage (Ritchie \& Hanway, 1993; Annonymous, 2013). Therefore, occurrence of water deficit stress during vegetative growth phases becomes detrimental to
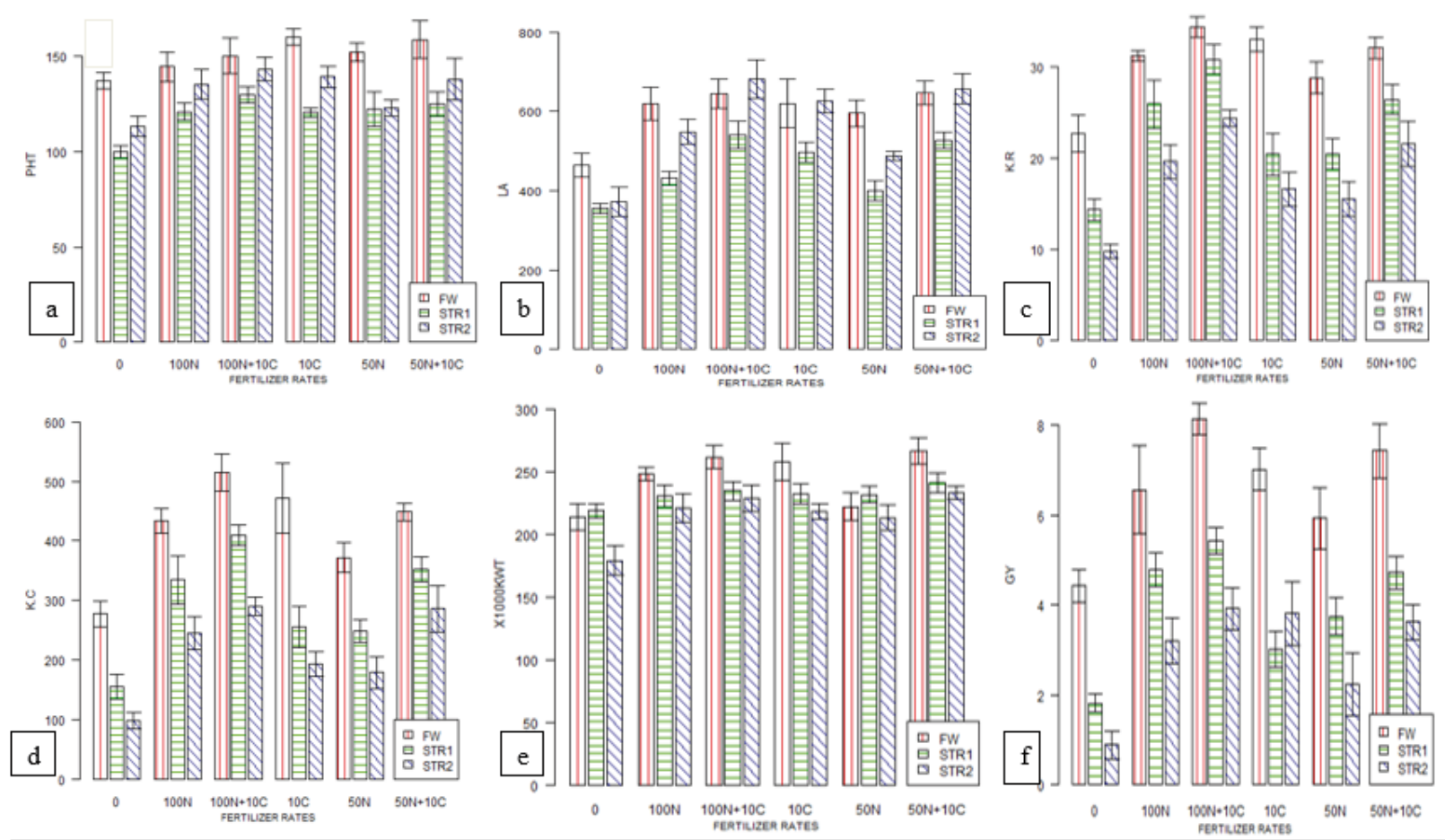

Figure 3: Water deficit stress and fertilizer interaction effects on (a) PHT (Plant Height) (b) LA (Leaf Area) (c) Number of K/R (Kernels/Row), (d) K/C (Kernels/cob), (e) 1000-Kernel weight and (f) GY(Grain Yield) of two maize varieties planted under three water deficit stress and six fertilizer application rates in Ibadan. FW = Full watering, STR1 = Water stress at vegetative growth stage STR 2 = Water stress at reproductive growth stage 
the final crop grain yield (Ritchie \& Hanway, 1993). This is because, water deficit stress during vegetative growth stage decreases plant source potential and assimilates level thereby decreasing grain weights (Borra’s et al., 2003; Fatemi et al., 2006 and Khalili et al. 2010)

The impact of preanthesis water deficit stress (STR2) in this study resulted in $55.37 \%$ loss in grain yield, this finding agreed with the reports of Denmead \& Shaw, (1960) and Sah et al. (2020). Farre \& Faci, (2009), and Mansouri, et al. (2010), which earlier inferred that grain yield of maize is highly determined by the amount of irrigation water. The number of ear formed per plant were not significantly different across the water deficit stress regime, but ears obtained from plants subjected to preanthesis water deficit stress (STR2) were smaller in size with few grains while some were even barren. The significant reduction in the number of grain per row and 1000-kernel weight under the water deficit stress observed in this study agreed with the earlier reports of Carpici (2009) and Kuscu (2010). In the view of Grant et al. (1989) and Hargurdeep \& Westgate (2010) water deficit stress during pre anthesis stage of maize development could be implicated for abnormal development of embryo sac, grain sterility and decreased fertile grain number. While imposition of water deficit stress during preanthesis growth stage resulted in reduced number of kernels per cob, kernel set per row and the total grain yield (sink limiting).

Increased fertilizer applications significantly enhance R/C, K/R, K/C, Weight of 1000-kernels and GY across the water deficit stress regime in this study. Deficiencies in $\mathrm{N}$ supply have been reported to impair pollination synchronization, increased kernel abortion (Uribelarrea et al., 2002; Uhart \& Andrade, 1995), resulting in reduced kernel number per plant and decrease grain yield observed in the fertilizer control (Carcova et al., 2000; Paponov et al., 2005). Apart from water, soil nutrient especially nitrogen also had significant impact on the yield components and grain yield of maize in this study. Increased maize growth and yield responses were obtained under increased fertilizer application rates especially when $10 \mathrm{tha}^{-1}$ of compost was added to each inorganic fertilizer rates of 50 and $100 \mathrm{~kg} \mathrm{ha}^{-1}$ respectively. Application of inorganic fertilizer with compost to crop has been reported to have the advantage of providing nutrients to meet crop nutrition requirements and maintain soil health (Abedi et al., 2010; Kazemeini et al., 2010; Efthimiadou et al., 2010). High level of micronutrient in the compost (Table 2) may have helped to improve general plant performance. Apart from water, soil nutrient especially nitrogen also had significant impact on the growth and yield components of maize in this study.

Application of nitrogen fertilizer have been shown to increased the uptake of other nutrients, this is because nitrogen enhances growth and development of small roots and root hairs which in turn facilitate the absorbing ability per unit of dry weight (Gheysari et al., 2009; Hammad et al., 2011). Nitrogen is also needed to establish and maintain the enzymatic processes essential for carbon utilization and growth, and is also a major constituent of endosperm storage protein (Cazetta et al., 1999; Duvnjak et al., 2021). The use of $10 \mathrm{tha}^{-1}$ of Tithonia poultry compost in combination to each of $100 \mathrm{~kg} \mathrm{~N}$ $\mathrm{ha}^{-1}$ and $50 \mathrm{~kg} \mathrm{~N} \mathrm{ha}^{-1}$ of nitrogen fertilizer significantly enhanced grain yield than sole applications of each of inorganic fertilizer rate in this study. The compost (Table 2 ) has a very high carbon to nitrogen ratio, also very rich in essential micronutrients needed for maize production. Application of inorganic fertilizer with compost to crop has been reported to have the advantage of providing nutrients to meet crop nutrition demands and maintain soil health (Efthimiadou et al., 2010). Compost had been reported to improve soil water holding capacity as well as buffering rapid changes in soil $\mathrm{pH}$ (Tambone et al., 2007; Zemánek, 2011).

The significant water regime by fertilizer interaction effects on the various growth and yield components in this study indicated that growth and yield increased resulting from fertilizer application depended on the availability of water (Pandey et al., 2000). Hence, adequate moisture availability is vital to nutrient mineralization, growth and grain yield of maize (Hokmalipour et al., 2010). Water deficit stress at the vegetative stage of growth not only deprived the plant of adequate moistures supply needed for cellular meristematic activities but also hinder nutrient supply which are needed for the development of yield component potential. Despite the impact of the water stress on the various yield components of maize, increased application of fertilizer was seen to enhanced grain yield of the two maize varieties. Increased nitrogen application has been shown to have the capability of improving drought tolerance and enhancing grain yield in maize (Boutras, 2001; Xu et al., 2005). Variety TZPBSR-W appeared to performed better than ILE-1-OB most especially under well watered condition but such superiority could not be maintain under the first and second water stress conditions as observed in the number of kernels per row and number of kernels per cob. The effect of water stress on seed formation, kernel set and grain yield was most severe during the reproductive growth stage and under reduced nutrient availability. Water stress and low nutrient availability might have reduced the sink strength and capacity of the maize plants which are determined by genetic and environmental factors (Alvarez Prado et al., 2014).

Moisture availability and nutrient availability to a large extent, determines seed formation, kernel set, and 
the final grain yield in this study. Nitrogen fertilizer effect on the various yield components and grain yield improved as the $\mathrm{N}$ application increases. Maize plant performed best when inorganic fertilizer was used along with organic fertilizer than when organic or inorganic fertilizer was applied alone. The result of the present finding on water regime nitrogen interaction also revealed that growth and yield components and grain yield performed better under adequate moisture availability. Nitrogen had been reported to improve water use efficiency in maize (Ogola et al., 2002). Growth and yield components were improved with increase $\mathrm{N}$ application even under water stress conditions. Therefore, optimization of $\mathrm{N}$ and water management could be an efficient way to attain sustainable agriculture. The two maize varieties were similar in yield responses to the varying stress periods and fertilizer application rates in the two years of the experimental studies. Similar report of variability in crop genotypic response under water stress had earlier been reported by Hufsteler et al., (2007); Abayomi \& Abidoye, (2009).

Application of $10 \mathrm{t} \mathrm{ha}^{-1}$ of Tithonia poultry compost alone to the maize field produced taller maize plants and broader leaves better than maize plants obtained when $100 \mathrm{~kg} \mathrm{~N} \mathrm{ha}^{-1}$ inorganic fertilizer were applied, but this alone could not sustain the plant adequately beyond the pollination process. The evidence of this was the rapid appearance of yellow lower leaves in treatment with $10 \mathrm{t}$ $\mathrm{ha}^{-1}$ (Tithonia poultry compost alone). Explanations for this could be that the $\mathrm{N}$ supply by the compost alone at the transition stage from vegetative to reproductive was not adequate enough for $\mathrm{N}$ demand for post pollination activities. Hence the need for remobilisation of $\mathrm{N}$ from the lower leaves for grain filling was inevitable.

\section{CONCLUSION}

Climate change and its associated attributes have impacted negatively on general crop development across the world. Drought emanating from erratic rainfall pattern has constituted serious menace to profitable maize production in the sub Saharan Africa. From this study it was obvious that water deficit stress reduced growth and yield performances of the two maize varieties resulting into grain yield losses of $41.0 \%$ and $55.37 \%$ under vegetative and reproductive stages water deficit stresses, respectively. However, this study has been able to explore soil fertility management at enhancing growth and yield performances of maize subjected to water deficit stress. Different rates of nitrogen fertilizer from inorganic, organic sources and their combinations were applied to the two maize varieties at different phenological growth -water deficit stages. From the result, it is obvious that
$50 \mathrm{~kg} \mathrm{~N}$ of inorganic fertilizer and $10.7 \mathrm{~kg} \mathrm{~N}$ of Tithonia Poultry Compost significantly enhance growth and yield performances of the two maize varieties across water stresses in this study. The $50 \mathrm{~kg} \mathrm{~N}$ of inorganic fertilizer represents half dose of recommended $100 \mathrm{~kg}$ $\mathrm{N}$ of nitrogen fertilizer (inorganic) application rate for the agro ecological zone of the country. Minimal use of inorganic fertilizer rate will help reduce environmental issues associated with the increase use of chemical fertilizers and cost of production. The maize varieties grown under $50 \mathrm{~kg} \mathrm{~N}^{-1}$ NPK-20-10-10 and $10.7 \mathrm{~kg} \mathrm{~N}^{-1}$ TPC subjected to water deficit stress must have benefited immensely from fast release of plant nutrient (inorganic fertilizer) with high; micronutrients, organic carbon content and moisture retention of compost. Augmenting reduced rate of inorganic fertilizer with Tithonia compost is hereby recommended for profitable maize production in derived savanna ecology of Nigeria. In spite of the numerous benefits associated with the use of compost, the bulkiness and availability of enough quantities for large scale maize production remains a great challenge. Farmers should be adequately trained on compost preparation techniques and the importance of combine use of inorganic and organic fertilizers to boost maize production in the face of the prevailing climate change. Government should support and empower unemployed youth to embrace commercial compost production so as to cater for the anticipated high compost demand by commercial farmers. More funding should be made available for soil fertility management and climate change adaptability studies.

Funding: This research was supported by Research grant From the Federal Ministry of Agriculture and Natural Resources and the Institute of Agricultural Research and Training, Moor Plantation, Ibadan, Nigeria.

\section{REFERENCES}

Abayomi, Y. A., \& Abidoye, T.O. (2009). Evaluation of cowpea genotypes for soil moisture stress tolerance under screen house conditions. African Journal of Plant Science, 3(10), 229-237. Online at http://www.academicjournals.org/AJPS

Abedi, T., Alemzadeh, A., \& Kazemeni, S.A. (2010). Effect of organic and inorganic fertilizer on grain yield and protein banding pattern of wheat. Australian Journal of Crop Science, 4, 384-389.

Alvarez Prado, S., Sadras, V.O., \& Borras, L. (2014). Independent genetic control of maize (Zea mays) kernel weight determination and its phenotypic plasticity. Journal of Experimental Botany, 65, 4479-4487. https://doi.org/10.1093/jxb/ eru215

Ammani, A.A., Ja’afaru, A.K., Aliyu, J.A., \& Arab, A.I. (2012). Climate change and maize production: Empirical evidence from Kaduna State. Journal of Agricultural Extension 
Nigeria, 16(1), 1-9. https://doi.org/10.4314/jae.v16i1.1

Anjorin, F.B. (2018). Effects of water deficit stress, inorganic and organic fertilizers on growth and yield performance of quality Protein maize. Ph.D dissertation University of Ibadan, Ibadan.

Anjorin, F.B., Adejumo, S.A., Are, K.S., \& Ogunniyan, D. J. (2017). Seedling establishment, biomass yield and water use efficiencies of four maize varieties as influenced by water deficit stress. Cercetări Agronomice în Moldova, 50(2), 21-34. https://doi.org/10.1515/cerce-2017-0012

Anjum S. A., Xie, X., Wang, L., Saleem, M. F., Man, C., \& Wang. L. (2011). Morphological, physiological and biochemical responses of plants to drought stress. African Journal of Agricultural Research, 6(9), 2026-2032.

Annonymous, (2013).Corn Growth Stages Channel.com Technology Development \& Agronomy, Musanto

Araus, J. L., Slafer, G.A., Royo, C., \& Serret, M.D. (2008). Breeding for yield potential and stress adaptation in cereals. Critical Reviews in Plant Sciences, 27(6), 377-412. https://doi. org/10.1080/07352680802467736

Bolaños, J., \& Edmeades, G.O. (1996). The importance of the anthesis-silking interval in breeding for drought tolerance in tropical maize. Field Crops Research, 48, 65-80. https:// doi.org/10.1016/0378-4290(96)00036-6

Borra's, L., Westgate, M.E., \& Otegui, M. E. (2003). Control of kernel weight and kernel water relation by post-flowering source-sink ratio in maize. Annals of Botany, 91, 857-867. https://doi.org/10.1093/aob/mcg090

Carpici, E.B. (2009). Evaluation of the effects of plant densities and nitrogen rates on stress physiology traits in silage corn (Zea mays L.) production. PhD thesis, Field Crops, Graduate School of Natural and Applied Sciences. Uludag University, Bursa, Turkey

Cazetta, J.O., Seebauer, J. R., \& Below, F.E. (1999). Sucrose and nitrogen supplies regulate growth of maize kernels. Annals of Botany, 84, 747-754. Article No. anbo.1999.0976, available online at http:\}\}www.idealibrary.com on. https://doi. org/10.1006/anbo.1999.0976

Chaves, M.M., Pereira, J.S., Maroco, J., Rodriques, M.L., Ricardo, M.L., Osorio, M.L., $\quad$ Carvatho, I., Faria, T., \& Pinheiro, C. (2002). How plants cope with water stress in the field photosynthesis and growth? Annals of Botany, 89, 907-916. https://doi.org/10.1093/aob/mcf105

Denmead, O.T., \& Shaw, R.H. (1960). The effects of soil moisture stress at different stages of growth on the development and yield of corn. Agronomy Journal, 52, 272-277. https:// doi.org/10.2134/agronj1960.00021962005200050010x

Edmeades, G.O. (2013). Progress in achieving and delivering tolerance in maize. An update, SAAA Ithaca, NY. Global Status of Commercialized Biotech/GM Crops: 1- 4.

Duvnjak, M., Kljak, K., \& Grbeša, D. (2021). Nitrogen Storage in Crops: Case Study of Zeins in Maize. DOI: 10.5772/intechopen. 95380. https://doi.org/10.5772/intechopen. 95380

Edmeades, G.O., J. Bolaños, S.C. Chapman, H.R. Lafitte., \& Bänziger, M. (1999). Selection for drought tolerance increases maize yields across a range of nitrogen levels. Crop Science, 39(4), 1306-1315. https://doi.org/10.2135/ cropsci1999.3951306x
Efthimiadou, A., Bilalis, D., Karkanis, A., \& Froud-Williams, B. (2010). Combined organic/inorganic fertilization enhance soil quality and increased yield, photosynthesis and sustainability of sweet maize crop. Australian Journal of Crop Science, 4(9), 722-729.

Eghball, B., \& Maranville, J.W. (1991). Interactive effects of water and nitrogen stresses on nitrogen utilization efficiency, leaf water status and yield of corn genotypes. Communications in Soil Science and Plant Analysis, 22, 1367-1382. https://doi.org/10.1080/00103629109368498

Farré, I., \& Faci, J.M. (2009). Deficit irrigation in maize for reducing agricultural water use in a Mediterranean environment. Agricultural Water Management, 96(3), 383-394. https://doi.org/10.1016/j.agwat.2008.07.002

Fatemi, R., Kahraryan, B., Ghanbary, A., \& Valizadeh, M. (2006). The evaluation of different irrigation regimes and water requirement on yield and yield components of corn. Journal of Agronomy and Crop Science, 12(1), 133-141.

Fernhill, (2011). Difference between compost and fertilizer. Retrieved online fernhillcompost.com, 3(15), 427-2821.

Francis, C.A., Rutger, J. N., \& Palmer, A. F. E. (1969). Rapid method for plant leaf area estimation in maize (Zea mays L.) Crop science, 9(5), 537-539. https://doi.org/10.2135/cro psci1969.0011183X000900050005x

Gheysari, M., Mirlatifi, S.M., Bannayan, M., Homaee, M., \& Hoogenboomb, G. (2009). Interaction of water and nitrogen on maize grown for silage. Agricultural Water Management, 96, 809-82. https://doi.org/10.1016/j.agwat.2008.11.003

Goldblatt, A. (2010). Agriculture: Facts and Trends, South Africa. Retrieved from http://aWSRssets.wwf.org.za/downloads/facts_brochure on 12/06/2017, 1-32.

Grant, R.F., Jackson, B.C., Kiniry, J.R., \& Arkin, G.F. (1989). Water deficit timing effects on yield components in maize. Agronomy Journal, 81, 61-65. https://doi.org/10.2134/agron j1989.00021962008100010011x

Hammad, H.M., Ahmad, A.A., Wajid, A., \& Akhter, J. (2011). Maize response to time and rate of nitrogen application. $\mathrm{Pa}$ kistan Journal of Botany, 43(4), 1935-1942.

Hargurdeep, S. S., \& Westgate, M. E. (2000). Reproductive development in grain crops during drought. Advances in Agronomy, 68(1), 59-96. https://doi.org/10.1016/S00652113(08)60843-3

Hokmalipour, S., Shiri-e-Janagard, M., Darbandi, M.H., Peyghami-e-Ashenaee, F., Hasanzadeh, M., Seiedi, M.N., \& Shabani, R. (2010). Comparison of agronomical nitrogen use efficiency in three cultivar of corn as affected by nitrogen fertilizer levels. World Applied Science Journal, 8(10), 1168-1174. http://www.redorbit.com/news/ science/1070340/the_effects_of_shortterm_compost

Hufsteler, E.V., Boerma, H.R., Carter, T.E., \& Earl, H.J. (2007). Genotypic variation for three physiological traits affecting drought tolerance in soybean. Crop Science, 47, 25-35. https://doi.org/10.2135/cropsci2006.04.0243

Imadi, S.R., Gul, A., Dikilitas, M., Karakas, S., Sharma, I., \& Ahmad P. (2016). Water stress: types, causes, and impact on plant growth and development. In: Ahmad P, ed. Water Stress and Crop Plants. Chichester, UK: John Wiley \& Sons, Ltd; 343-355. doi: 10.1002/9781119054450.ch21. https://doi.org/10.1002/9781119054450.ch21 
Jongdee, B., Fukai, S., \& Cooper, M. (2002). Leaf water potential and osmotic adjustment as physiological traits to improve drought tolerance in rice. Field Crops Research, 76, 153-163. https://doi.org/10.1016/S0378-4290(02)00036-9

Khalili, M., Moghaddam, M., Kazemi Arbat, H., Shakiba, M.R., Kanooni, H., \& Choukan, R. (2010). Effect of drought stress on different corn genotypes. Journal of Agricultural Science, 2(20), 67-84.

Kuscu, H. (2010). Effects of deficit irrigation on yield and yield components of maize grown under Bursa conditions. $\mathrm{PhD}$ thesis, Irrigation and Agricultural Structures, Graduate School of Natural and Applied Sciences, Uludag University, Bursa, Turkey.

Mansouri-Far, C.S.A., Sanavy, M.M., \& Saberali, S.F. (2010). Maize yield response to deficit irrigation during low sensitive growth stages and nitrogen rate under semi-arid climatic conditions. Agricultural Water Management, 97(1), 12-22. https://doi.org/10.1016/j.agwat.2009.08.003

Monneveux, P.C., Sánchez, D., Beck, C., \& Edmeades, G.O. (2006). Drought improvement in maize source population: evidence of progress. Crop Science, 41, 180-191. https://doi. org/10.2135/cropsci2005.04-0034

Ngetich, F.K., Shisanya, C.A., Mugwe, J., Mucheru-Muna, M., \& Mugendi, D. (2012). The Potential of Organic and Inorganic Nutrient Sources in Sub-Saharan African Crop Farming Systems - A Global Perspective, Dr. Joann Whalen (Ed.), ISBN: 978-953-307-945-5, In Tech, Available from: http:// www.intechopen.com/books/soil-fertility-improvement-and integrated-nutrient-management-a-global-perspective on 04/06/2016,Pp 1 -27.

Ogola, J.B.O., Wheeler, T.R., \& Harris, P.M. (2002). Effects of nitrogen and irrigation on water use of maize crops. Field Crops Research, 78, 105-117. www.elselvier.com. https://doi.org/10.1016/S0378-4290(02)00116-8

Pandey, R.K., Marienville, J.W., \& Adum, A. (2000). Deficit irrigation and nitrogen effect on maize in a Sahelian environment. I .Grain yield components. Agricultural Water Management, 46, 1-13. https://doi.org/10.1016/S03783774(00)00073-1

Paponov, I.A., Sambo, P., Erley, G.S.A., Presterl, T., Geiger, H.H., \& Engels, C. (2005). Kernel set in maize genotypes differing in nitrogen use efficiency in response to resource availability around flowering. Plant and Soil, 272, 101-110. https://doi.org/10.1007/s11104-004-4210-8

Ritchie, S.W., Hanway, J.J., \& Benson, G.O. (1993). How a Corn Plant Develops. Iowa State Univ. p. Rpt. No. 48. Available online at http://maize.agron.iastate.edu/corngrows.html

Rufino, C.A., Fernandes-Vieira, J., Martín-Gil, J., Júnior, J.S.A., Tavares, L.C., Fernandes-Correa, M., \& Martín-Ramos, P. (2018). Water stress influence on the vegetative period yield components of different maize genotypes. Agronomy, 8(8),
151. https://doi.org/10.3390/agronomy8080151

Sah, R.P., Chakraborty, M., Prasad, K. et al. (2020). Impact of water deficit stress in maize: Phenology and yield components. Scientific Report, 10, 2944. https://doi.org/10.1038/ s41598-020-59689-7

Sanginga, N., \& Woomer, P. L. (2009). Integrated soil fertility management in Africa: principles, practices and developmental process. Tropical Soil Biology and Fertility Institute of the International Centre for Tropical Agriculture, Nairobi, 1-263.

Scoones, I., \& Toulmin, C. (1998). Soil nutrient balances: What use for policy? Agriculture, Ecosystems \& Environment, 71, 255-267. https://doi.org/10.1016/S0167-8809(98)00145-5

Smale, M., Byerlee, D., \& Jayne, T.S. (2011). Maize Revolutions In Sub-Saharan Africa. World Bank Policy Research Working Paper, 5659, 1-47. https://doi.org/10.1596/1813-9450-5659

STAR, (2014). Statistical Tool For Agricultural Research Version version 2.0.1 Biometrics and Breeding Informatics, PBGB Division, International Rice Research Institute, Los Baños,Laguna.

Tambone, F., Genevini, P.D., \&'Imporzano, G.A. (2007). The effects of short-term compost application on soil chemical properties and on nutritional status of maize plant. Compost Science and Utilization, 15(3), 176-183. https://doi.org/ 10.1080/1065657X.2007.10702330

Tan, Z. X., Lal, R., \& Wiebe, K. D. (2005). Global soil nutrient depletion and yield reduction. Journal of Sustainable Agriculture, 26(1), 123-146. Available online at http://www. haworthpress.com/web/JSA. https://doi.org/10.1300/ J064v26n01_10

Uhart, S.A., \& Andrade, F.H. (1995). Nitrogen deficiency in maize. II.Carbon-nitrogen interaction effects on kernel number and grain yield. Crop Science, 35, 1384-1389. https://doi.org/10.2135/cropsci1995.0011183X00350005002 $1 \mathrm{x}$

Uribelarrea, M., Carcova, J., Otegui, M.E., \& Westgate, M.E. (2002). Pollen production, pollination dynamics, and kernel set in maize. Crop Science, 42, 1910-1918. https://doi. org/10.2135/cropsci2002.1910

Vanlauwe, B., Descheemaeke, K., \& Giller, K.E et al. (2015). Integrated soil fertility management in sub-Saharan Africa: unravelling local adaptation. Soil, 1, 1239-1286. https://doi.org/10.5194/soil-1-491-2015

Xu, Z.Z., Yu, Z.W., Wang, D., \& Zhang, Y.L. (2005). Water use water Kisintili applications to yield. Turkish nitrogen accumulation and translocation for winter. Journal of Agriculture and Forestry, 23, 233-241.

Zemánek, P. (2011). Evaluation of compost influence on soil water retention. Acta Universitatis Agriculturae et Silviculturae Mendelianae Brunensis, 54(3), 227-232. https://doi. org/10.11118/actaun201159030227 